\title{
GROWTH AND PRODUCTIVITY OF CORN AS AFFECTED BY MULCHING AND TILLAGE IN ALLEY CROPPING SYSTEMS
}

\author{
Emanoel Gomes de Moura*; Jonas Mendes Albuquerque; Alana das Chagas Ferreira Aguiar \\ UEMA - Programa de Pós-Graduação em Agroecologia - C.P. 3004 - 65054-970 - São Luís, MA - Brasil. \\ *Corresponding author <egmoura@elo.com.br>
}

\begin{abstract}
Alley cropping has been considered a means of intensifying land use sustainably as an alternative to slash and burn agriculture in tropical regions. An experimental trial was used to evaluating the growth and productivity of corn under alley cropping to test the viability of this system as a sustainable land use practice in an amazonian Ultisol. The experimental layout was a completely randomized block design with four replications of six treatments: mulch with 13.4 and $8.9 \mathrm{t} \mathrm{ha}^{-1}$ of pigeon pea, and a control treatment without mulch of pigeon pea, with or without tillage. Sustainability of soil and crop were determined from changes on physical properties, such as total porosity, air capacity, available water capacity of the soil, net assimilation rate, crop growth rate, and leaf area index, as well as several productivity parameters, including average weight of ears, weight of 100 grains, and total dry matter. Both mulching and tillage increased the air capacity. Mulching of tilled areas protects the soil against the rainfall impact and prevented its recompaction. The reduced air capacity of the soil had a negative impact on the net assimilation rate, resulting in lower productivity in the no-mulch and no-till plots, mainly due to the reduction of grain weight.
\end{abstract}

Key words: air capacity, recompaction, pigeon pea

\section{CRESCIMENTO E PRODUTIVIDADE DE MILHOAFETADOS PELA COBERTURA E PREPARO DO SOLO SOB UM CULTIVO EMALÉIAS}

\begin{abstract}
RESUMO: O sistema de cultivo em aléias é considerado uma forma de uso intensivo do solo, como uma alternativa ao sistema de corte e queima nas regiões tropicais. O cultivo em aléias foi testado para verificar sua viabilidade como prática de uso sustentável de um Argissolo da Amazônia. Foram avaliados o crescimento e a produtividade do milho sob esse sistema de cultivo. $\mathrm{O}$ arranjo experimental utilizado foi em blocos ao acaso, com quatro repetições e seis tratamentos: cobertura do solo com 13,4 e 8,9 $\mathrm{t} \mathrm{ha}^{-1}$ de feijão guandu, um tratamento testemunha sem cobertura do solo com palha ("mulch"), com ou sem preparo. Foram determinadas porosidade total, capacidade de aeração e capacidade de água disponível do solo, taxa de assimilação líquida, taxa de crescimento da cultura, índice de área foliar e parâmetros de produtividade, como massa de espigas, massa de 100 grãos e matéria seca total. A cobertura e o preparo aumentaram a capacidade de aeração e essa cobertura das áreas preparadas evitou a recompactação. A reduzida capacidade de aeração teve um impacto negativo na taxa de assimilação líquida, o que resultou em produtividade baixa nas parcelas não cobertas e não preparadas, principalmente devido a redução do peso de grãos.

Palavras-chave: capacidade de aeração, recompactação, feijão guandu
\end{abstract}

\section{INTRODUCTION}

The physical indicators of soil quality are very important for plant growth in the equatorial region, notably water capacity, air capacity, temperature and soil strength (Jayawardane \& Chan, 1994; Moura, 2006). The use of mulch can have significant influence on these indicators under tropical conditions. Mulching creates a more favorable environment for the macrofauna, which modify the soil by creating pores, thereby increasing the air capacity and the soil perme- ability (McKenzie \& Dexter, 1993). Mulching also has a moderating effect on the soil temperature and contributes considerably to the conservation of soil moisture, as compared to exposed soils. Both of these factors favor soil macrofauna activity (Mando \& Miedema, 1997). The tillage practices affect the activity of groups of arthropod fauna with digging or burrowing habits that may also play an important role in the improvement of the physical soil conditions enhancing the aeration and water movement (Marasas et al., 2001). 
Annual rainfall is greater than $2000 \mathrm{~mm}$ throughout considerable areas of the southeastern Amazon region. Ultisols are predominantly composed of fine sand and silt, and they are highly susceptible to crusting and compaction because of their weak structure. Plant response to improved soil management practices, as reflected, i.e., by growth rates and yields, strongly depends on the improvement of the physical properties of soil fertility (Moura, 2006). Mulching is the single most important management practice in the rainy season, achieving improved crop yields without adjusting the soil chemical fertility by liming and/or fertilization. Unfortunately, the planting time in the region is preceded by a dry season of five months. It is therefore not feasible to derive biomass production for mulching from annuals. In addition residues of pigeon pea can help to maintain the soil fertility through recycling nutrients mainly nitrogen and calcium (Aguiar, 2006).

Though an increase in the macro porosity of the arable soil layer can also be achieved by tillage, soil permeability will not necessarily increase. This is because soil permeability largely depends on the continuity and length of the large pores (Ball, 1981), which may be adversely affected by tillage. Improved soil physical conditions as a result of tillage are furthermore frequently of short duration, due to deterioration of the porous structure and reconsolidation of the soil. The rate at which soil recompaction occurs depends on the cumulative rainfall and on the overall stability of the soil structure (Busscher et al., 2002).

Alley cropping has been considered a manner of intensifying land use, as an alternative to slash and burn agriculture in tropical regions. This system can be defined as the growing of arable crops between hedgerows of planted shrubs and trees, preferably leguminous species, which are periodically pruned for mulch production and to prevent shading the companion crops. This can be important for the Ultisols of humid tropical regions in which the weak structure of the soil, added to high rainfall, turns the maintenance of rootability in the arable layer in to a major challenge, so as to achieve the sustainability of land use.

The overall objective is to develop alternative sustainable land-use practices for Alfisols in the Amazon region. This study compares the growth and productivity of corn in the rainy season, with and without tillage, under three levels of mulch, produced in alley cropping systems of pigeon pea (Cajanus cajan).

\section{MATERIAL AND METHODS}

This study was conducted in São Luís, State

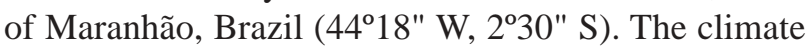

of the region is humid tropical, with the average annual temperature ranging between $24^{\circ} \mathrm{C}$ and $26^{\circ} \mathrm{C}$, and an average annual rainfall above $2000 \mathrm{~mm}$. The soil is an Ultisol with the following characteristics: $\mathrm{pH} 4.3$ in $0.01 \mathrm{M} \mathrm{CaCl}_{2}$; organic $\mathrm{C} 12 \mathrm{~g} \mathrm{~kg}^{-1}$; exchangeable acidity 33, and CEC $49.2 \mathrm{mmol}_{(+)} \mathrm{dm}^{-3}$; $\mathrm{Ca} 2, \mathrm{Mg} 3$, and $\mathrm{K}$ $1.2 \mathrm{mmol}_{(+)} \mathrm{dm}^{-3}$; P $7 \mathrm{~g} \mathrm{dm}^{-3}$ (resin), base saturation $27 \%$, coarse sand 260 , fine sand 560, silt 80 , clay 100 $\mathrm{g} \mathrm{kg}^{-1}$; bulk density $1.74 \mathrm{t} \mathrm{m}^{-3}$. The experimental layout was a factorial $3 \times 2$, with four replications in completely randomized blocks design and the following treatments: $0,8.9$ and $13.4 \mathrm{tha}^{-1}$ of pigeon pea mulch, with or without tillage. Plot size was $6.0 \mathrm{~m} \times 5.0 \mathrm{~m}$ and the sampling area had $12 \mathrm{~m}^{2}$.

Soil tillage was manual, using hoes, with depth of $0-20 \mathrm{~cm}$. The pigeon pea rows were established two years before sowing the corn, which was a double hybrid, variety AG 1051, in February, 1998. Branches were cut into pieces of $180 \mathrm{~cm}$ average length and distributed evenly among the corn rows, shortly after sowing. The corn was sown in $1 \mathrm{~m}$ wide rows, with five plants per meter. N-P-K fertilizer was applied at sowing at a rate of 10-60-50 $\mathrm{kg} \mathrm{ha}^{-1}$, in the form of urea, triple super phosphate and potassium chloride. Two subsequent doses of 40 $\mathrm{kg} \mathrm{N} \mathrm{ha}{ }^{-1}$, using urea, were applied at 35 and 50 days after ear emergence.

Soil density, total porosity, air capacity and available water capacity were determined upon ripening of the corn in May 1998. For this purpose, three undisturbed samples were taken from the center of the alley of each plot at a depth of $10 \mathrm{~cm}$, using cylindrical rings of $100 \mathrm{~cm}^{3}$. Total porosity was calculated with the equation $\varphi=1-\rho_{\mathrm{s}} / 2.65$, were $\rho_{\mathrm{s}}$ is the density of soil and 2.65 the assumed particle density (in $\mathrm{g} \mathrm{cm}^{-1}$ ), (Moura et al., 1992). Air capacity, corresponding to the volume of macropores, was calculated as the difference of mass between the water saturated sample and the sample equilibrated at $-10 \mathrm{kPa}$, determined in a tank of glass balls. The available water capacity was calculated from the difference of soil mass between -10 and $-1500 \mathrm{kPa}$.

Three plants were collected per plot every week for assessment of leaf area index, dry matter production, crop growth rate and net assimilation rate. The leaf area index was determined from excised leaves with a Licor foliar area meter. The same material was subsequently dried in an oven at $60^{\circ} \mathrm{C}$ with forced air circulation (until mass constancy for dry matter determination). Plant growth parameters were determined according to Portes \& Castro Júnior (1991), assessing the following productivity parameters: weight of ears, weight of 100 grains and total grain yield, in June (1998). 
Comparisons between treatments were made using analysis of variance (ANOVA). Significance level was set at $P<0.05$. Comparisons between means were made using Tukey test.

\section{RESULTS AND DISCUSSION}

During the growth period of 75 days total rainfall at the site was $570 \mathrm{~mm}$, of which $110 \mathrm{~mm}$ fell during the ten days of flowering stage. The physical quality indicators were affected both by tillage and mulching (Table 1). The greater porosity that developed in all plots with thicker treatment suggests that mulch reduced the recompaction of the tilled plots. In the no-till plots the use of mulch may have stimulated "invertebrate engineers" activity, as suggested by Jouquet at al. (2006) and usually observed under the mulch at harvest time. In plots with tillage, mulching prevented porosity from declining by as much as $7 \%$. The recompaction in the no-mulch plots occurred almost entirely at the expense of the soil aeration capacity, or of pores larger than $60 \mu \mathrm{m}$, but did not affect the meso pores that are responsible for maintaining available water capacity. Soil aeration capacity declined to around $0.11 \mathrm{~m}^{3} \mathrm{~m}^{-3}$ in the plots with no mulch (Table 2). This level may be critical for gas diffusion in the soil (Thomasson, 1978; Sallam et al., 1984). The destruction or absence of aggregates in sandy soils results in water occupation in the same pores through which soil gases normally circulate. When this hap- pens, root respiration is the first physiological process affected, followed by decreased water and nutrient uptake and a decline of the photosynthetic capacity (Currie, 1961; Glinski \& Stepniewski, 1986).

Plants from plots with reduced air capacity were less productive in the flowering phase (Figure 1). The relatively high rainfall during this period was likely responsible for this finding. Under these conditions and with the high equatorial temperatures, the restricted aeration effect can be exacerbated by the low availability of $\mathrm{O}_{2}$ in the soil which reduces the photosynthentic capacity of leaves (Fausey et al., 1985). Tillage and lower mulching rate positively affected all treatments.

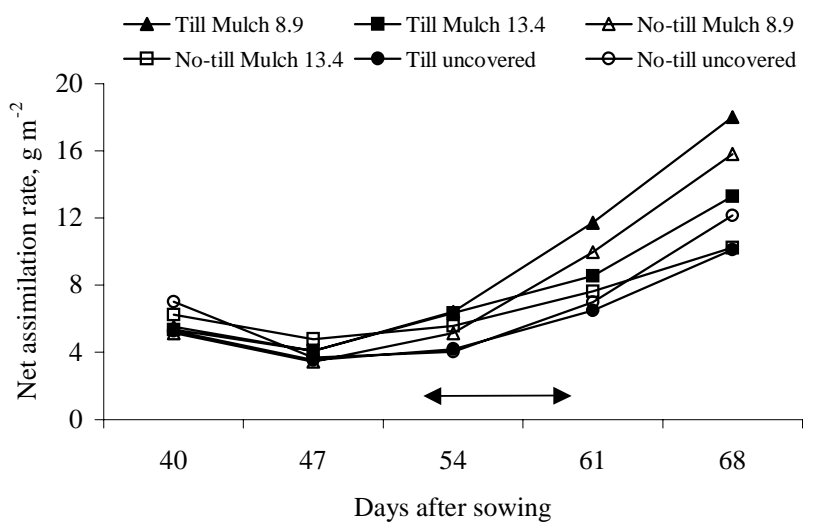

Figure 1 - Net assimilation rate of corn in till and no-till soil, with pigeon pea mulch of 13.4 and $8.9 \mathrm{tha}^{-1}$ and in uncovered soil.

$\longleftrightarrow$ Flowering stage period (50 to 60 days after sowing)

Table 1 - Total porosity ( $\varphi$ t), air capacity (AirC) and available water capacity (AwC) in till and no-till plots under three mulching levels, 0 - $20 \mathrm{~cm}$ depth.

\begin{tabular}{ccccccc}
\hline \multirow{2}{*}{ Mulch } & \multicolumn{5}{c}{ Physical Indicators } \\
\cline { 2 - 6 } & $\varphi \mathrm{t}$ till & $\varphi \mathrm{t}$ no-till & AirC till & AirC no-till & AwC till & AwC no-till \\
\hline $\mathrm{t} \mathrm{ha}^{-1}$ & $0.44 \mathrm{Ab}$ & $0.43 \mathrm{Ab}$ & $0.11 \mathrm{Ab}$ & $0.11 \mathrm{Aab}$ & $0.13 \mathrm{Aa}$ & $0.10 \mathrm{Aa}$ \\
0 & $0.49 \mathrm{Aa}^{*}$ & $0.45 \mathrm{Bb}$ & $0.14 \mathrm{Aab}$ & $0.09 \mathrm{Bb}$ & $0.17 \mathrm{Aa}$ & $0.10 \mathrm{Aa}$ \\
8.9 & $0.49 \mathrm{Aa}$ & $0.48 \mathrm{Aa}$ & $0.16 \mathrm{Aa}$ & $0.14 \mathrm{Aa}$ & $0.13 \mathrm{Aa}$ & $0.15 \mathrm{Aa}$ \\
13.4 & & &
\end{tabular}

* Means followed by same letters (within each indicator), capitals in the rows and lower case in the columns, are not different $(P<0.05$, Tukey test).

Table 2 - Yield components in till and no-till plots under three mulching levels.

\begin{tabular}{|c|c|c|c|c|c|c|c|c|}
\hline \multirow{3}{*}{ Mulch } & \multicolumn{8}{|c|}{ Yield components } \\
\hline & Till & No-till & Till & No-till & Till & No-till & Till & No-till \\
\hline & \multicolumn{2}{|c|}{100 grain weight } & \multicolumn{2}{|c|}{ Ear weight } & \multicolumn{2}{|c|}{ Yield } & \multicolumn{2}{|c|}{ Total dry matter } \\
\hline $\mathrm{t} \mathrm{ha}^{-1}$ & ------- & g-a. & - & - & -..... kg & $\mathrm{ha}^{-1} \ldots \ldots$ & - & $-\cdots-\cdots$ \\
\hline 0 & $33.05 \mathrm{Aa}$ & $29.50 \mathrm{Bb}$ & $9.75 \mathrm{Ab}$ & $9.10 \mathrm{Ab}$ & $7.94 \mathrm{Ab}$ & $6.63 \mathrm{Bb}$ & $8.10 \mathrm{Ab}$ & $7.74 \mathrm{Ab}$ \\
\hline 8.9 & $34.27 \mathrm{Aa}^{*}$ & $32.30 \mathrm{Ba}$ & $13.52 \mathrm{Aa}$ & $10.81 \mathrm{Ba}$ & $9.58 \mathrm{Aa}$ & $8.68 \mathrm{Ba}$ & $12.90 \mathrm{Aa}$ & $10.40 \mathrm{Ba}$ \\
\hline 13.4 & $33.62 \mathrm{Aa}$ & $33.74 \mathrm{Aa}$ & $10.42 \mathrm{Ab}$ & $9.25 \mathrm{Bb}$ & $8.68 \mathrm{Aab}$ & 7.74 Bab & $13.43 \mathrm{Aa}$ & $10.44 \mathrm{Ba}$ \\
\hline
\end{tabular}

*Means followed by same letters (within each indicator), capitals in rows and lower case in columns, are not different $(P<0.05$, Tukey test). 
Leaf growth is driven by an internal mechanism that regulates the shoot/root ratio (Sharp \& Davies, 1979; Bradford \& Hsiao, 1982). In this way the increase in the water absorption area counterbalances the excessive expansion of the points of losses by transpiration during growth. Under conditions of anoxia, the shoot and root growth rates are also related (Glinski \& Stepniewski, 1986), but the shoot/ root ratio is greater due to a relative decline in the root growth rate, although the leaves growth rate decreases too, as in the treatment no-till uncover (Figure 2).

The decline in the root growth rate results in a decline in water and nutrient absorption and causes reduction in the overall crop growth rate as found in the treatments till uncover, no-till uncover and notill mulch 13.4, of this trial (Figure 3). In the flowering phase, 50 to 60 days after sowing, the plants in the no-mulch and no-till plots grew less than half as much as the plants in the treatments with mulch till and no-till (Figure 3). The interaction between the higher net assimilation rate and the major leaf area index of plants, with mulch till or notill, accounted for its larger growth. The response of crop growth to tillage is superior to the treatment with no-tillage, when comparing plots with the same mulch levels.

Increased growth does not always result in greater grain yield, since the definition of preferential sinks for photosynthetic assimilates within the plants can be affected by the treatments. In our case, however, the mulch effect accounted for the differences in the weight of 100 grains, between the mulch and no mulch plots in no-till (Table 2), and mulching was the main factor contributing to the higher yields. The greater productivity was obtained partly from the increase in the length of the corn ear, but mainly by the increase in average weight of individual grains (Maddonni et al., 1999). This is the result of the growth of the ear of corn during two stages (Hay,

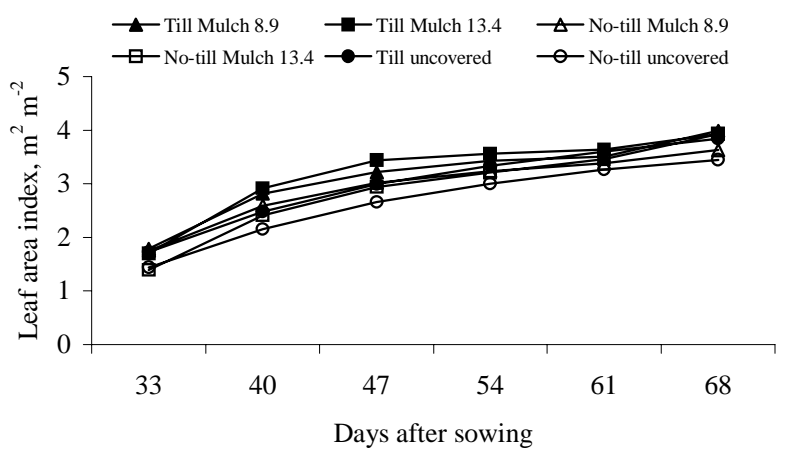

Figure 2 - Leaf area index of corn in till and no-till, with pigeon pea mulch of 13.4 and $8.9 \mathrm{tha}^{-1}$ and in uncovered soil.

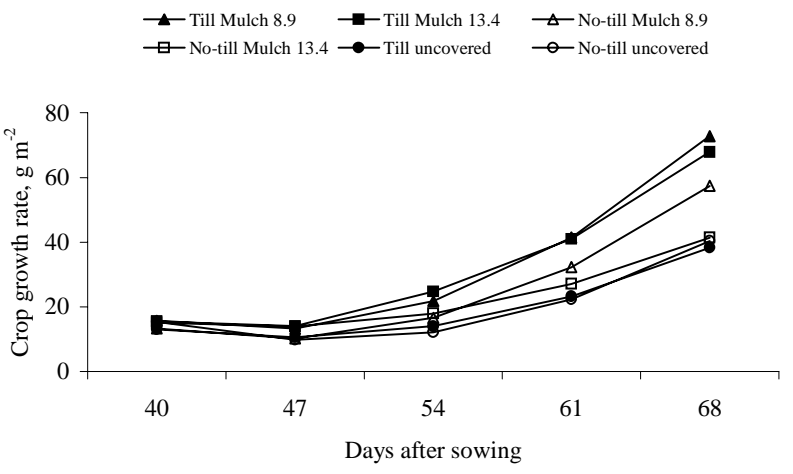

Figure 3 - Crop growth rate of corn in till and no-till soil, with mulch of 13.4 and $8.9 \mathrm{tha}^{-1}$ with pigeon pea and in uncovered soil.

1995). The first stage begins after the fertilization of the ovary and corresponds to the period of formation of the ear. The growth rate of the grain during the second stage, effectively a period of grain filling, determines the final weight of the grains. The largest differences in the net assimilation rates between the mulched plots with tillage and no-mulch without tillage, hence with less air capacity, occurred during this stage which coincides with the intense rainfall period. Furthermore, there was a big effect on amount of dry matter produced, which was 50\% greater in mulched than in no-mulch plots, due to higher crop rate growth accumulated.

\section{CONCLUSIONS}

In the Ultisols of the Amazon region, the productivity of corn proved to be strongly related to physical indicators of soil quality, such as air capacity, total porosity, and bulk density. Although the physical indicators can be enhanced by tillage, under high rainfall conditions, in conjunction with an unstable soil structure, exposed soils are prone to re-compaction, which decreases air capacity to a threshold value, in which the combination of a lesser leaf area index and a lesser net assimilation rate, causes a reduction in plants' growth and yield. Although the quality of soil can be enhanced by tillage, it is necessary to protect the soil surface against raindrop impacts with mulching, so as to achieve and maintain favorable soil conditions for agricultural production.

\section{REFERENCES}

AGUIAR, A.C.F. Sustentabilidade do sistema plantio direto em Argissolo no trópico úmido. Botucatu: UNESP/FCA, 2006. 57p. Tese (Doutorado).

BALL, B.C. Pore characteristics of soils from two cultivation experiments as show by gas diffusivities and permeabilities and air-filled porosities. Journal of Soil Science, v.32, p.483498, 1981. 
BRADFORD, K.L.; HSIAO, T.C. Physiological responses to moderate water stress. In: LANGE, O.L.; NOBEL, P.S.; OSMOND, C.B.; ZIEGLER, H. (Ed.) Encyclopedia of plant physiology: physiological plant ecology. II. Water relations and carbon assimilation. New York: Springer, 1982. p.263-324.

BUSSCHER, W.J.; BAUER, P.J.; FREDERICK, J.R. Recompaction of the coastal loamy sand after deep tillage as a function of subsequent cumulative rainfall. Soil and Tillage Research, v.68, p.49-57, 2002.

CURRIE, J.A. Gaseous diffusion in the aeration of aggregated soils. Soil Science, v.92, p.40-45, 1961.

FAUSEY, N.R.; SOUND, T.T.; McDONALD Jr., M.B. Response of ten corns cultivars to flooding. Transactions of the ASAE, v.28, p.1794-1797, 1985.

GLINSKI, J.; STÊPNIEWSKI, W. Soil aeration and its role for plants. Boca Raton: CRC Press, 1986. 229p.

HAY, R.K.M. Harvest index: a review of its use in plant breeding and crop physiology. Annals of Applied Biology, v.126, p.197-216, 1995.

JAYAWARDANE, N.S.; CHAN, K.Y. The management of soil physical properties limiting crop production in Australian sodic soils: a review. Australian Journal of Soil Research, v.32, p.13-44, 1994.

JOUQUET, P.; DAUBER, J.; LAGERLÖF, J.; LAVELLE, P.; LEPAGE, M. Soil invertebrates as ecosystem engineers: intended and accidental effects on soil and feedback loops. Applied Soil Ecology, v.32, p.153-164, 2006.

MADDONNI, G.A.; URRICARIET, S.; GHERSA, C.M.; LAVADO, R.S. Assessing soil quality in the Rolling Pampa, using soil properties and maize characteristics. Agronomy Journal, v.91, p.280-287, 1999.

MANDO, A.; MIEDEMA, R. Termite-induced change in soil structure after mulching degraded (crusted) soil in the Sahel. Applied Soil Ecology, v.6, p.241-249, 1997.
MARASAS, M.E.; SARANDÓN, S.J.; CICCHINO, A.C. Changes in soil arthropod functional group in a wheat crop under conventional and no tillage systems in Argentina. Applied Soil Ecology, v.18, p.61-68, 2001.

McKENZIE, B.M.; DEXTER, A.R. Size and orientation of burrows made by the earthworms Aporrectodea rosea and A. caliginosa. Geoderma, v.56, p.233-241, 1993.

MOURA, E.G. Agroambientes de transição avaliados numa perspectiva da agricultura familiar. In: MOURA, E.G. (Ed.) Agroambientes de transição: entre o trópico úmido e o semi-árido do Brasil. São Luís: Universidade Estadual do Maranhão, 2006. cap.1, p.15-51.

MOURA, E.G.; VIEIRA, S.R.; CARVALHO, A.M. Avaliação da capacidade de aeração e de água disponível dos solos de duas transeções na baixada maranhense. Revista Brasileira de Ciência do Solo, v.16, p.7-18, 1992.

PORTES, T.A.; CASTRO JÚNIOR, L.G. Análise de crescimento de plantas: um programa computacional auxiliar. Revista Brasileira de Fisiologia Vegetal, v.3, p.53-56, 1991.

SALLAM, A.; JURY, W.A.; LETEY, J. Measurements of gas diffusion coefficient under relatively low air-filled porosity. Soil Science Society of America Journal, v.48, p.3-6, 1984.

SHARP, R.E.; DAVIES, W.J. Solute regulation and growth by roots and shoots of water-stressed maize plants. Planta, v.147, p.4349, 1979

THOMASSON, A.J. Towards an objective classification of soil structure. Journal Soil Science, v.29, p.38-46, 1978.

Received February 17, 2006

Accepted November 14, 2007 